\title{
Pengaruh Penggunaan Limbah Cair Pemindangan Ikan dalam Ransum terhadap Kecernaan Protein, Lemak dan Energi Metabolis pada Itik Persilangan Mojosari-Peking
}

\section{The Effect of Liquid Waste of Pindang Fish In Ration on Protein Digestibility, Fat and Metabolic Energy of Mojosari-Peking Duck}

\author{
D. Maharani*, L. D. Mahfudz dan I. Mangisah \\ Fakultas Peternakan dan Pertanian, Universitas Diponegoro, Semarang, 50275 \\ *E-mail: deltamaharani.95@gmail.com
}

(Diterima: 26 Oktober 2017; Disetujui: 12 Desember 2017)

\begin{abstract}
ABSTRAK
Penelitian ini bertujuan untuk mengkaji pengaruh penggunaan limbah cair pemindangan ikan sebagai bahan pakan itik dengan level yang berbeda terhadap nilai kecernaan nutrisi dan energi metabolis ransum pada itik Mojosari Peking berumur 3 minggu sebanyak 120 ekor dengan bobot badan rata-rata $520,30 \pm 47,82$ g. Bahan pakan yang digunakan adalah jagung, bekatul, konsentrat CP 144 dan limbah cair pemindangan ikan. Penelitian menggunakan Rancangan Acak Lengkap (RAL) dengan 4 perlakuan dan 5 ulangan, setiap ulangan terdapat 6 ekor itik. Perlakuan yang diterapkan adalah penggunaan limbah cair pemindangan ikan dengan level: $\mathrm{T} 0=0 \%, \mathrm{~T} 1=2,5 \%, \mathrm{~T} 2=5 \%$ dan $\mathrm{T} 3=7,5 \%$. Parameter yang diamati meliputi konsumsi ransum, kecernaan protein, kecernaan lemak dan energi metabolis ransum. Data dianalisis menggunakan analisis ragam dengan uji F. Hasil penelitian menunjukkan bahwa penggunaan limbah cair pemindangan ikan tidak berpengaruh nyata terhadap konsumsi ransum, kecernaan protein, kecernaan lemak dan nilai energi metabolis ransum. Kesimpulan dari penelitian ini adalah penggunaan limbah cair pemindangan ikan dalam ransum hingga taraf 7,5\% belum mampu meningkatkan konsumsi ransum, kecernaan protein dan lemak serta energi metabolis ransum.
\end{abstract}

Kata kunci: energi metabolis, itik, kecernaan, limbah cair pemindangan ikan

\section{ABSTRACT}

This aim of this study was to determine the effect of liquid waste of pindang fish in ration on the value of nutrient digestibility and metabolic energy ration of Mojosari Peking duck. The research materials used were 120 ducks which are 3 weeks old with an average initial body weight of $520.30 \pm$ $47.82 \mathrm{~g}(\mathrm{CV}=9,19 \%)$. Feed ingredients used were corn, rice bran, CP 144 concentrate and liquid waste of pindang fish. Experiment design was used a Completely Randomized Design (CRD) with 4 treatments and 5 replications, and each replication consisted of 6 ducks. The treatments were used of liquid waste of pindang fish in rations at levels: $T 0=0 \%, T 1=2.5 \%, T 2=5 \%$ and $T 3=7.5 \%$. Parameters observed were consumption, protein digestibility, fat digestibility and metabolic energy ration. The data was analyzed using variance analysis with $F$ test. The results showed that the used of liquid waste of pindang fish have no significant effect $(P>0.05)$ on consumption, protein digestibility, fat digestibility and metabolic energy of rations. The conclusion, that the used of liquid waste of pindang fish in ration up to the level of $7.5 \%$ is not increasing consumption, protein digestibility, fat digestibility and metabolic energy ration.

Keywords: digestibility, duck, the liquid waste of pindang fish, metabolic energy

\section{PENDAHULUAN}

Ikan pindang merupakan produk olahan ikan yang dibuat dengan merebus ikan dalam suasana bergaram selama waktu tertentu.
Berdasarkan data Kementerian Perinsdustrian Republik Indonesia tahun 2016, terdapat sekitar 718 perusahaan pengolahan ikan di Indonesia termasuk usaha pengolahan ikan pindang. Industri pengolahan pindang 
sebagian besar tersebar diwilayah Jawa Tengah dan Jawa Timur seperti Pekalongan, Pati, Rembang, Situbondo, Jember dan Trenggalek. Tercatat terdapat 253.600 ton produksi ikan pindang di Indonesia menurut data Kementerian Kelautan dan Perikanan tahun 2016. Produk olahan ikan pindang tersebut menghasilkan limbah cair hasil perebusan ikan yang masih mengandung zat nutrisi seperti protein dan lemak. Kandungan nutrisi didalam limbah cair pemindangan ikan antara lain kadar air 83,44\%, protein $0,32 \%$ dan lemak $10,95 \%$ yang di analisis di Laboratorium Terpadu, Universitas Diponegoro. Limbah cair pemindangan ikan juga mengandung minyak ikan seperti asam lemak essensial Omega-3 dan Omega-6 yang terlarut selama proses perebusan ikan.

Terdapatnya kandungan asam lemak essensial didalam limbah cair pemindangan ikan dapat dimanfaatkan sebagai bahan campuran dalam ransum itik karena memiliki peran dalam meningkatkan kecernaan nutrisi itik. Kandungan asam lemak essensial dalam limbah dapat dimanfaatkan untuk membantu proses absorbsi vitamin-vitamin yang larut dalam lemak, mengurangi sifat berdebu ransum dan meningkatkan palatabilitas pakan yang akan berpengaruh pada tingkat konsumsi ransum. Tingginya lemak dalam limbah juga diharapkan mampu menambah ketersediaan energi dalam ransum sehingga dapat membantu kerja saluran pencernaan dalam mencerna ransum yang akhirnya juga dapat meningkatkan kecernaan nutrisi ternak (Sany et al., 2015). Asam lemak linolenat dan asam arakhidonat (yang termasuk kedalam Omega-6) serta asam eikosapentaenoat atau EPA (yang termasuk dalam Omega 3) menjadi prekusor hormon yaitu tromboksan dan prostaglandin yang dikenal juga sebagai prostanoid yang memiliki peran dalam fungsi sekresi dan pencernaan yaitu berperan dalam sekresi asam, sekresi enzim pencernaan dan mempengaruhi gerak peristaltik didalam usus dalam proses penyerapan nutrisi (Estiasih, 2009). Omega-3 dan Omega-6 juga ikut berperan dalam menjaga kelenturan (fluiditas) membran sel serta membantu mempermudah transport nutrisi dan penyerapan nutrisi (Catala, 2013).

Limbah cair pemindangan ikan juga mengandung garam $(\mathrm{NaCl})$ dari proses perebusan ikan dalam mengawetkan ikan pindang sebanyak 12,08\%. Kadar garam tersebut dapat menyebabkan itik mengkonsumsi air lebih banyak sehingga fungsi ginjal dapat terganggu dan proses metabolisme itik menurun, hal tersebut akan menyebabkan tingkat konsumsi pakan itik menjadi rendah. Watkins et al. (2005) menyatakan batas toleransi unggas terhadap konsumsi garam yaitu $0,5 \%$, kemudian masalah yang ditimbulkan apabila konsumsi $\mathrm{NaCl}$ tinggi pada unggas yaitu menyebabkan turunnya tingkat pertambahan bobot badan, konversi pakan serta feses yang dikeluarkan menjadi lebih encer.

Penelitian ini bertujuan untuk mengkaji pengaruh penggunaan limbah cair pemindangan ikan dalam ransum terhadap konsumsi ransum, kecernaan protein, kecernaan lemak dan energi metabolis ransum pada itik persilangan Mojosari Peking.

\section{METODE}

Penelitian ini dilaksanakan pada tanggal 16 Maret - 8 Mei 2017 di kandang unggas Fakultas Peternakan dan Pertanian Universitas Diponegoro, Semarang.

\section{Materi Penelitian}

Materi yang digunakan dalam penelitian ini adalah 120 ekor itik persilangan Mojosari Peking (MP) umur 3 minggu yang memiliki bobot badan rata-rata 520,30 $\pm 47,82$ g (CV=9,19\%). Limbah cair pemindangan ikan diperoleh dari industri pemindangan ikan di Desa Bajomulyo Kecamatan Juwana Kabupaten Pati.

Perlengkapan yang digunakan dalam penelitian ini antara lain timbangan digital kapasitas $50 \mathrm{~kg}$ untuk menimbang pakan, kandang litter ukuran $1 \mathrm{~m}$ x $1 \mathrm{~m}$ sebanyak 20 petak sebagai kandang perlakuan, kandang 
Tabel 1. Kandungan Nutrisi Bahan Penyusun Ransum (Kering Udara)

\begin{tabular}{|c|c|c|c|c|c|c|}
\hline Bahan Pakan & EM (Kkal/kg) & PK (\%) & SK (\%) & LK $(\%)$ & $\mathrm{Ca}(\%)$ & $\begin{array}{l}\mathrm{P}(\%) \\
\end{array}$ \\
\hline Limbah cair pindang ${ }^{1)}$ & $1.705,00^{2)}$ & 0,32 & 0,18 & 10,95 & - & - \\
\hline Jagung giling ${ }^{3)}$ & $3.321,00^{2)}$ & 8,45 & 8,33 & 3,01 & 0,03 & 0,23 \\
\hline Konsentrat CP 1443) & $2.500,00$ & 37,00 & 6,00 & 2,00 & 12,00 & 1,20 \\
\hline Bekatul $^{3)}$ & $2.887,00^{2)}$ & 12,50 & 16,70 & 14,34 & 0,32 & 1,70 \\
\hline
\end{tabular}

Sumber : ${ }^{1}$ Hasil Analisis Laboratorium Terpadu UNDIP, 2016.

${ }^{2}$ Hartadi et al. (1980)

${ }^{3}$ Hasil Analisis Proksimat Laboratorium Ilmu Nutrisi Pakan, Fakultas Peternakan dan Pertanian, Universitas Diponegoro, 2016.

Tabel 2. Kandungan Nutrisi Ransum Perlakuan

\begin{tabular}{lcccc}
\hline \multirow{2}{*}{ Bahan Pakan } & \multicolumn{4}{c}{ Perlakuan } \\
\cline { 2 - 5 } & T0 & T1 & T2 & T3 \\
\hline Limbah Cair Pindang (\%) & 0,00 & 2,50 & 5,00 & 7,50 \\
Jagung Kuning (\%) & 49,00 & 46,50 & 44,00 & 40,50 \\
Bekatul (\%) & 20,00 & 20,00 & 20,00 & 20,00 \\
Konsentrat (\%) & 31,00 & 31,00 & 31,00 & 32,00 \\
Total & 100,00 & 100,00 & 100,00 & 100,00 \\
\hline Kandungan Nutrisi & \multicolumn{4}{c}{} \\
\hline EM (Kkal/kg) & $2.979,69$ & $2.939,29$ & $2.898,89$ & $2.850,28$ \\
PK (\%) & 18,11 & 17,91 & 17,70 & 17,79 \\
SK (\%) & 9,28 & 9,08 & 8,87 & 8,65 \\
LK (\%) & 4,96 & 5,16 & 5,36 & 5,55 \\
Ca (\%) & 3,80 & 3,80 & 3,80 & 3,91 \\
P (\%) & 0,82 & 0,82 & 0,81 & 0,82 \\
\hline
\end{tabular}

Keterangan: Berdasarkan hasil perhitungan nutrisi bahan penyusun ransum.

battery 20 buah digunakan saat total koleksi, tempat pakan, tempat minum, sekam, lampu, thermohygrometer, semprotan, nampan penampung ekskreta, plastik, spidol, label, dan $\mathrm{HCl} 0,1 \mathrm{~N}$.

\section{Metode Penelitian}

Metode penelitian meliputi tahap persiapan terdiri dari persiapan kandang dan pengadaan bahan pakan. Proses pengadaan limbah cair pindang yaitu dimasukan ke dalam wadah tertutup dan disimpan dalam lemari es agar tidak terjadi kontaminasi yang

dapat merusak sifat dan kandungan nutrisi didalam limbah. Bahan pakan penyusun ransum perlakuan meliputi bekatul, jagung, konsentrat dan limbah cair pemindangan ikan yang disusun berdasarkan isoenergi dan isoprotein. Kandungan nutrisi bahan pakan dapat dilihat pada Tabel 1, sedangkan komposisi dan kandungan nutrisi ransum dapat dilihat pada Tabel 2.

Tahap perlakuan yang dilakukan meliputi itik persilangan MP yang berumur 2 minggu dimasukkan ke dalam kandang litter ukuran $1 \mathrm{~m}$ x $1 \mathrm{~m}$. Ransum perlakuan diberikan ke ternak itik pada umur 3 minggu sampai dengan umur 8 minggu. Ransum perlakuan yang diberikan berupa ransum yang ditambahkan air 50\% dari berat ransum (semi basah). Pencampuran limbah cair pemindangan ikan dalam ransum dilakukan dengan mencampurkan terlebih dahulu limbah cair pindang kedalam air dengan tujuan agar proses pencampuran limbah cair pindang kedalam ransum dapat merata. Pencampuran limbah cair pindang dilakukan saat pemberian ransum pakan, hal ini untuk menghindari agar ransum tidak disimpan terlalu lama dan berjamur. Pemberian pakan dilakukan 2 kali sehari pada pagi hari pukul $06.00 \mathrm{WIB}$ dan 
sore hari pukul 15.00 WIB dan pemberian air minum dilakukan secara ad libitum.

Penelitian ini menggunakan rancangan acak lengkap (RAL) dengan 4 perlakuan dan 5 ulangan, dimana tiap unit percobaan terdiri dari 6 ekor itik. Ransum perlakuan yang diberikan selama penelitian antara lain :

T0: Ransum dengan $0 \%$ Limbah cair pindang T1: Ransum dengan 2,5\% Limbah cair pindang

T2: Ransum dengan 5\% Limbah cair pindang

T3: Ransum dengan 7,5\% Limbah cair pindang

Pengambilan data dimulai pada minggu

ke-3 hingga minggu terakhir penelitian. Parameter yang diamati antara lain konsumsi ransum, kecernaan protein, kecernaan lemak, dan nilai energi metabolis. Pengambilan data konsumsi ransum dilakukan dengan menimbang jumlah pemberian ransum dikurangi sisa ransum setiap hari. Pengukuran data kecernaan nutrisi dilakukan saat itik mencapai umur 8 minggu dengan metode total koleksi yang dilakukan selama 3 hari. Sampel total koleksi dianalisis untuk mengetahui data kadar protein feses, kadar lemak feses dan kadar Gross Energi feses.

Data kecernaan protein diperoleh dengan menggunakan rumus sebagai berikut (Tillman et al., 1998):

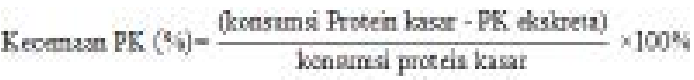

Data kecernaan lemak diperoleh dengan menggunakan rumus sebagai berikut (Tillman et al., 1998):

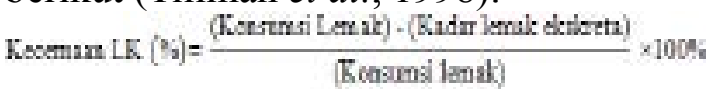

Data energi metabolis ransum diperoleh dengan menggunakan rumus sebagai berikut (Sibbald dan Wolynetz, 1985):

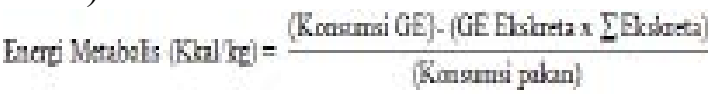

Ket :

Konsumsi GE = Gross energi terkonsumsi $(\mathrm{kkal} / \mathrm{kg})$

GE ekskreta $=$ Gross energi ekskreta itik $(\mathrm{kkal} / \mathrm{kg})$

Data penelitian dianalisis menggunakan analisis ragam dengan uji $\mathrm{F}$ pada $\mathrm{P} 0,05 \%$ dan dilanjutkan dengan Uji Jarak Berganda Duncan's apabila diperoleh hasil yang berbeda nyata.

\section{HASIL DAN PEMBAHASAN}

Rataan hasil penelitian pengaruh penggunaan limbah cair pemindangan ikan terhadap konsumsi ransum, kecernaan protein, kecernaan lemak dan energi metabolis ransum pada itik persilangan Mojosari Peking disajikan pada Tabel 3.

\section{Konsumsi Ransum}

Hasil analisis ragam menunjukkan bahwa perlakuan penggunaan limbah cair pemindangan ikan dalam ransum tidak berpengaruh nyata $(\mathrm{P}>0,05)$ terhadap konsumsi ransum itik Mojosari Peking umur 8 minggu (Tabel 3).

Penggunaan limbah cair pemindangan ikan dengan taraf $2,5 \%, 5 \%$ dan $7,5 \%$ dalam ransum tidak memberikan pengaruh nyata terhadap konsumsi ransum, hal ini dapat disebabkan karena ransum itik tiap perlakuan disusun berdasarkan kandungan energi yang sesuai kebutuhan nutrisinya. Anggorodi (1985) menyatakan bahwa kandungan energi dalam ransum akan sangat menentukan banyaknya jumlah ransum yang dikonsumsi. Ransum dengan kandungan energi yang rendah akan menyebabkan itik mengkonsumsi pakan lebih banyak hingga kebutuhan energinya tercukupi, sebaliknya apabila kadar energi pakan tinggi maka konsumsi itik akan menurun. Purba dan Ketaren (2011) menyatakan kandungan zat gizi termasuk energi metabolis yang diberikan ke ternak itik sesuai dengan kebutuhan nutrisinya akan sangat mendorong jumlah ransum yang dikonsumsi untuk pertumbuhan itik.

Penggunaan limbah cair pemindangan ikan dalam ransum diharapkan mampu meningkatkankonsumsiransumkarenaadanya 
kandungan lemak yaitu untuk meningkatkan palatabilitas ransum, namun pemberian limbah cair pindang ikan hingga 7,5\% tidak menyebabkan perubahan kandungan nutrisi dalam ransum khususnya lemak sehingga pengaruh perlakuan tidak berpengaruh nyata. Anggorodi (1995) menyatakan bahwa lemak dalam ransum ternak unggas digunakan untuk meningkatkan energi ransum dan tingkat palatabilitas. Swennen et al. (2004) menyatakan bahwa perbedaan level lemak dalam ransum mampu mempengaruhi tingkat konsumsi ransum unggas, diketahui pakan A (kandungan lemak 106,1 g/kg) memiliki jumlah konsumsi pakan sebesar $50 \mathrm{~g} / \mathrm{kg}$, sedangkan pakan B (kandungan lemak 43,3 g/ $\mathrm{kg}$ ) jumlah konsumsi pakannya sebesar $40 \mathrm{~g} /$ $\mathrm{kg}$.

Kandungan asam lemak essensial dalam limbah cair pindang dalam ransum masih terlalu sedikit yaitu pada pakan T1, T2 dan T2 berkisar 0,0004\%, 0,0008\% dan $0,0012 \%$. Rendahnya kandungan asam lemak essensial tidak menyebabkan tingkat palatabilitas ransum meningkat. Menurut Iriyanti et al. (2005), bahwa imbangan komposisi asam lemak tidak jenuh dalam ransum dapat mempengaruhi palatabilitas ransum, yaitu ransum dengan kombinasi minyak ikan lemuru dan minyak kelapa sawit 4\% meningkatkan konsumsi ransum karena menjadikan pakan lebih palatable dibandingkan ransum yang tidak ditambahkan minyak.

\section{Kecernaan Protein Kasar}

Hasil analisis ragam menunjukkan bahwa perlakuan penggunaan limbah cair pemindangan ikan dalam ransum tidak berpengaruh nyata $(\mathrm{P}>0,05)$ terhadap kecernaan protein itik mojosari peking umur 8 minggu (Tabel 3).

Nilai kecernaan protein itik persilangan Mojosari-Peking umur 8 minggu pada masingmasing perlakuan berkisar antara 73,26 $78,39 \%$. Pada penelitian yang dilakukan oleh Saputra et al. (2016) menyatakan bahwa itik Mojosari umur 8 minggu memiliki tingkat kecernaan protein kasar yang berkisar antara 73,7 - 81,1\%. Penggunaan limbah cair pemindangan ikan dalam ransum tidak berpengaruh nyata terhadap nilai kecernaan protein dapat disebabkan karena jumlah konsumsi protein pakan rata-rata sama pada tiap perlakuan. Tingkat konsumsi protein itik tiap perlakuan rata-rata sama dapat disebabkan karena jumlah konsumsi ransum sama pada tiap perlakuan. Sari et al. (2014) yang menyatakan bahwa konsumsi ransum yang tinggi maka ternak mengkonsumsi protein yang tinggi, sebaliknya apabila konsumsi ransum rendah maka konsumsi protein juga rendah. Prawitasari et al. (2015) menyatakan bahwa nilai kecernaan nutrisi dapat dipengaruhi oleh jenis bahan ransum, kandungan nutrisi, suhu, laju perjalanan ransum melalui pencernaan dan komposisi ransumnya.

Perlakuan tidak berpengaruh nyata terhadap kecernaan protein kasar juga dapat disebabkan karena kandungan asam lemak essensial Omega-3 dan Omega-6 dalam limbah pindang ikan sangat rendah yaitu berkisar $0,0004 \%$ (ransum perlakuan T1), $0,0008 \%$ (ransum perlakuan T2) dan $0,0012 \%$ (ransum perlakuan T3), sehingga jumlah kandungan asam lemak essensial tersebut belum dapat memberikan pengaruh yang signifikan terhadap kecernaan protein itik Mojosari Peking. Berdasarkan penelitian yang dilakukan oleh Pambuko (2016) bahwa itik lokal yang mendapatkan penambahan minyak ikan lemuru dalam ransum sebanyak $4 \%$ berpengaruh nyata meningkatkan kecernaan protein itik. Wildan (2000) menyatakan bahwa kandungan Omega-3 dan Omega-6 pada minyak ikan lemuru yaitu $10,58 \%$ dan 5,62\%. Estiasih (2009) menyatakan bahwa asam lemak Omega-6) dan Omega 3 menjadi prekusor pembentukan hormon seperti tromboksan dan prostaglandin yang memiliki peran dalam fungsi sekresi dan sistem pencernaan yaitu berperan dalam sekresi asam, sekresi enzim pencernaan dan mempengaruhi gerak peristaltik di dalam usus. 


\section{Kecernaan Lemak Kasar}

Hasil analisis ragam menunjukkan bahwa perlakuan penggunaan limbah cair pemindangan ikan dalam ransum tidak berpengaruh nyata $(\mathrm{P}>0,05)$ terhadap kecernaan lemak itik mojosari peking umur 8 minggu (Tabel 3).

Nilai kecernaan lemak kasar itik persilangan Mojosari-Peking pada masingmasing perlakuan berada pada kisaran normal yaitu antara 76,22 - 83,45\%. Pada penelitian yang dilakukan oleh Widiyastuti et al. (2007) menyatakan bahwa dengan pemberian perlakuan tepung kepala udang dalam ransum itik menghasilkan nilai kecernaan lemak kasar yang berkisar antara $71-86,7 \%$. Faktor yang menyebabkan penggunaan limbah cair pindang tidak berpengaruh nyata terhadap kecernaan lemak adalah jumlah konsumsi ransum itik yang tidak jauh berbeda menghasilkan jumlah konsumsi lemak yang rata-rata juga sama. Lokapirnasari et al. (2015) menyatakan bahwa faktor yang dapat mempengaruhi kecernaan nutrisi meliputi jenis ternak, komposisi pakan, jumlah konsumsi pakan, level pemberian ransum dan cara penyediaan ransum.

Perlakuan tidak berpengaruh nyata terhadap kecernaan lemak kasar juga dapat disebabkan karena kandungan asam lemak essensial Omega-3 dan Omega-6 dalam limbah pindang ikan sangat rendah yaitu berkisar $0,0004 \%$ (ransum perlakuan T1), 0,0008\% (ransum perlakuan T2) dan 0,0012\% (ransum perlakuan T3), sehingga jumlah kandungan asam lemak essensial tersebut belum dapat memberikan pengaruh yang signifikan terhadap kecernaan lemak itik Mojosari Peking. Berdasarkan penelitian yang dilakukan oleh Pambuko (2016) bahwa itik lokal yang mendapatkan penambahan minyak ikan lemuru dalam ransum sebanyak 4\% berpengaruh nyata meningkatkan kecernaan lemak itik. Wildan (2000) menyatakan bahwa kandungan Omega-3 dan Omega-6 pada minyak ikan lemuru yaitu $10,58 \%$ dan $5,62 \%$. Sany et al. (2015) menyatakan bahwa asam lemak Omega-6 bertugas sebagai prekusor pembentukan prostaglandin yang berperan merangsang motilitas usus halus dan berperan dalam proses penyerapan nutrisi bagi ternak sehingga dapat mempengaruhi nilai kecernaan nutrisi.

\section{Energi Metabolis}

Hasil analisis ragam menunjukkan bahwa perlakuan penggunaan limbah cair pemindangan ikan dalam ransum tidak berpengaruh nyata $(\mathrm{P}>0,05)$ terhadap energi metabolis itik mojosari peking umur 8 minggu (Tabel 3).

Nilai rata-rata energi metabolis ransum pada itik persilangan Mojosari-Peking pada penelitian ini berkisar antara 2.934,16 $3.153,05 \mathrm{kkal} / \mathrm{kg}$. Nilai energi metabolis itik persilangan Mojosari-Peking pada penelitian lebih tinggi dibandingkan hasil penelitian nilai energi metabolis itik lokal yang dilakukan oleh Mangisah et al. (2009) yaitu rata-ratanya $2.227,67-2.387,87 \mathrm{kkal} / \mathrm{kg}$. Tingginya hasil nilai energi metabolis ini dapat disebabkan karena umur itik dan jenis itik yang digunakan berbeda sehingga mempengaruhi kebutuhan energi itik dalam melakukan aktivitas.

Faktor yang menyebabkan tidak berpengaruhnya perlakuan terhadap energi metabolis yaitu penggunaan limbah cair pemindangan ikan dalam ransum tidak mempengaruhi kandungan nutrisi pada ransum tiap perlakuan sehingga nilai kecernaan zat nutrisi termasuk protein dan lemak sama. Kandungan nutrisi pakan yang dapat dicerna oleh itik akan digunakan untuk menghasilkan energi dan diperlukan untuk pertumbuhan itik. Hal ini sesuai pendapat Rizal (2006) yang menyatakan bahwa energi dapat berasal dari zat nutrisi dalam pakan yang masuk kedalam tubuh seperti protein, lemak dan karbohidrat yang mengalami proses metabolisme dalam tubuh sehingga akan menghasilkan energi dalam bentuk ATP. Wahju (1997) menyatakan bahwa nilai energi metabolis ransum dapat diketahui dengan menghitung energi yang dihasilkan dari zat nutrisi yang dapat dicerna dari pakan seperti protein, lemak, karbohidrat, bahan ekstra tanpa nitrogen dan serat kasar dari ransum basal. 


\section{KESIMPULAN}

Data hasil penelitian menunjukkan bahwa penggunaan limbah cair pemindangan ikan hingga taraf $7,5 \%$ dalam ransum itik persilangan Mojosari Peking belum dapat meningkatkan konsumsi ransum, kecernaan protein kasar, kecernaan lemak kasar dan nilai energi metabolis ransum pada itik persilangan Mojosari Peking.

\section{DAFTAR PUSTAKA}

Anggorodi, H.R. 1995. Nutrisi Aneka Ternak Unggas. Gramedia Pustaka Utama, Jakarta.

Anggorodi, H.R. 1985. Kemajuan Mutakir dalam Ilmu Makanan Ternak Unggas. Universitas Indonesia Press.

Catala, A. 2013. Five decades with polyunsaturated fatty acids : chemical synthesis, enzymatic formation, lipid peroxidation and its biological effects. J. Lipids. 1 (1):1-20.

Estiasih, T. 2009. Minyak Ikan Teknologi dan Penerapannya untuk Pangan dan Kesehatan. Graha Ilmu, Yogyakarta.

Hartadi, H., S. Reksohadiprodjo, S. Lebdosukojo dan A.D. Tillman. 1980. Tabel Komposisi Bahan Makanan Ternak Untuk Indonesia. Gajah Mada University Press, Yogyakarta.

Honarbakhsh, S., M. Zaghari and M. Shivazad. 2007. Interactive effect of dietary betaine and saline water on carcass traits of broiler chicks. J. Bio. Sci.7 (7) : 1208 - 1214.

Iriyanti, N., T. Yuwanta, Zuprizan dan S. Keman. 2005. Pengaruh penggunaan asam lemak rantai panjang dalam pakan terhadap penampilan dan profil darah serta gambaran ovarium ayam kampong betina. Buletin Peternakan. 29 (4): 177-184.

Lokapirnasari, W.P., M.M. Fadli, R.T.S. Adikara dan Suherni. 2015. Suplementasi spirulina pada formula pakan mengandung bekatul fermentasi mikroba selulolitik terhadap kecernaan pakan. J. Agroveteriner. 3(2): 137-144.

Mangisah, I., B. Sukamto dan M.H. Nasution. 2009. Implementasi daun encek gondok fermentasi dalam ransum itik. J. Indon. Trop. Anim. Agric. 34 (2) : 127-133.

Modather, M.H.Y. 2000. The Effect of Sodium Chloride Levels In Drinking Water on Broiler Performance. (Thesis). Faculty of Animal Production. University of Gezira.

Pambuko, S.F. 2016. Pengaruh suplementasi minyak ikan lemuru dan 1-karnitin dalam ransum terhadap kecernaan protein dan lemak kasar itiklokal jantan (anas plathyrynchos). Tesis. Fakultas Pertanian. Universitas Sebelas Maret.

Prawitasari, R.H., V.D.Y.B. Ismadi dan I. Estiningdiarti. 2015. Kecernaan protein kasar dan serat kasar serta laju digesta pada ayam arab yang diberi ransum dengan berbagai level Azolla microphylla. J. Anim. Agric. 1 (1) : 471-483.

Purba, M. dan P. Ketaren. 2011. Konsumsi dan konversi pakan itik lokal jantan umur delapan minggu dengan penambahan santoquin dan vitamin $\mathrm{E}$ dalam pakan. J. Ilmu Teknologi dan Veteriner. 16 (4) : $280-287$.

Rizal, Y. 2006. Ilmu Nutrisi Unggas. Andalas University Press, Padang.

Saputra, Y.A., I. Mangisah dan B. Sukamto. 2016. Pengaruh penambahan tepung kulit bawang terhadap kecernaan protein kasar pakan, pertambahan bobot badan dan persentase karkas itik Mojosari. J. Ilmu-ilmu Peternakan. 26 (1) : $29-36$.

Sany, S.W., S.R. Herwantari, Sudipya dan S.H. Purnomo. 2015. Pengaruh suplementasi minyak ikan dan L-karnitin dalam pakan jagung kuning terfermentasi terhadap kecernaan pakan dan performa puyuh (Coturnix coturnix japonica). Buletin Peternakan. 39 (1) : 31-41. 
Sari, K.A., B. Sukamto dan B. Dwiloka. 2014. Efisiensi penggunaan protein pada ayam broiler dengan pemberian pakan mengandung tepung daun kayambang (salvinia molesta). J. Agripet. 14 (2) : $76-83$.

Sibbald, I R. dan M.S. Wolynetz. 1985. Estimates of retained nitrogen used to correct estimates of bioavailable energy. J. Poultry Sci. 64 : 1506-1513.

Swennen, Q., G.P.J. Jansens, E. Decuypere and J. Buyse. 2004. Effects of substitution between fat and protein on feed intake and its regulatory mechanisms in broiler chickens: energy and protein metabolism and diet-induced thermogenesis. J. Poultry Science. 83:1997-2004.

Tillman, A.D., H. Hartadi, S. Reksohadiprodjo, S. Prawirokusumo dan S. Lebdosoekojo. 1998. Ilmu Makanan Ternak Dasar. Gadjah Mada University
Press, Yogyakarta.

Wahju, J. 1997. Ilmu Nutrisi Unggas. Cetakan ke-4. Gajah Mada University Press, Yogyakarta.

Watkins, S.E., C.A. Fritts, F. Yan, M.L. Wilson and P.W. Waldroup. 2005. The interaction of sodium chloride level in poultry dringking water and diet of broiler chickens. J. Appl. Poul. Res. 14 : 55-59.

Widiyastuti, T., C.H. Prayitno dan Sudibya. 2007. Kecernaan dan intensitas warna kuning telur itik lokal yang mendapat pakan tepung kepala udang, tepung daun lamtoro dan suplementasi L-Carnitin. J. Animal Production. 9 (1) :30-35.

Wildan, S. 2000. Perbandingan kandungan Omega-3 dan Omega-6 dalam minyak man lemuru dengan teknik kromatografi. Temu Teknil Fungsional non Peneliti. Balai Penelitian Ternak. Bogor. 